\title{
The influence of financial performance and macroeconomic on financing risk in Islamic banks
}

\author{
Dita Putri Angraini ${ }^{1}$, Heri Sudarsono$^{1}$, Sella Fitri Anindita ${ }^{3}$ \\ ${ }^{1}$ Faculty of Business and Economics, Universitas Islam Indonesia, Indonesia \\ ${ }^{3}$ Research Spesialist Danareksa, Jakarta, Indonesia \\ *Corresponding author:17313189@student.uii.ac.id
}

\author{
Article History \\ Received, 07 November 2020 \\ Revised 1, 21 November 2020 \\ Revised 2, 5 December 2020 \\ Accepted, 7 December 2020
}

\begin{abstract}
Purpose: The aim of this research is to identify the influence of microeconomic and macroeconomic variables toward non-performing financing of Islamic Commercial Banks in Indonesia.
\end{abstract}

Methodology: Microeconomic variables include CAR, FDR, BOPO, ROA, while macroeconomic variables include IPI, BI Rate, Inflation and SBIS for the period of 2015 to 2019. The data analysis method in this study is auto-regressive distributed lag (ARDL) using EViews 10 tool which can analyze the relationship between independent and dependent variables in the long-term and the short-term.

Findings: This study shows that CAR has a positive and insignificant effect on NPF. Furthermore, BOPO, ROA, BI Rate have a significant positive effect on $\mathrm{NPF}$, but FDR, inflation and SBIS have a significant negative effect on NPF. In the long-term, CAR, IPI and SBIS have a negative and insignificant effect on NPF, but BI Rate has a positive and insignificant effect. Suggestion in this research is to solve better research, so further research should be carried out by including a longer period of time.

Practical implications: Islamic Bank Directors need to pay attention to the movement of $\mathrm{BOPO}$ and $\mathrm{ROA}$ which tend to consistently have a positive effect on the NPF level.

Originality: This study presents the long-term and the short-term relationships of specific Islamic banking variables and macroeconomic variables on NPF in Indonesia.

Keywords: Non-performing financing, Auto-Regressive Distributed Lag, Islamic bank.

Cite this article:

Angraini, D., Sudarsono, H., \& Anindita, S. (2020). The influence of financial performance and macroeconomic on financing risk in Islamic banks. Asian Journal of Islamic Management, 2(2), 138-152. doi:https://doi.org/10.20885/ajim.vol2.iss2.art6

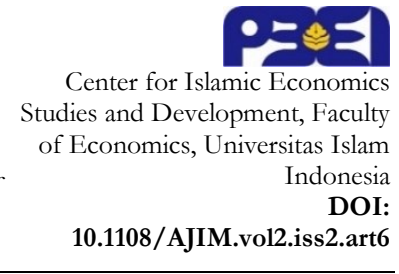

\section{Introduction}

The bank is an institution that has a strategic role in developing the economy. This role can be seen from the function of the bank which can collect funds from the public. These funds can be in the form of savings which are then distributed back to the public in the form of loans or financing. Banking role as an intermediation aims to improve people's standard of living. Meanwhile, Islamic bank is defined as a banking institution which all of its activities are in accordance with the principles of sharia (Islamic values). Banks operating under sharia principles have changed the lending distribution system to financing distribution. This is because financing has elements of agreement and transparency. 
In Law Number 10 of 1998 concerning Islamic banking, it is stated that the function of a bank as an intermediary institution is a form of financing distribution. There are several provisions that regulate banking on the financing distribution system for Islamic Banks (Sudarsono et al. 2019). This is due to an important role in managing the liquidity of Islamic banks. Active and smooth financing management can affect the level of liquidity and improve bank's soundness. Therefore, banks can avoid the risk if the management of financing is going well (Supriani \& Sudarsono, 2018). There are several ways in looking at the risk profile of Islamic banks. One of them is the risk that occurs due to customer failure to fulfill their obligations based on the agreement with the bank. The indicator that is often used in observing the level of customer fluency is the Non-Performing Financing (NPF) ratio.

NPF is the ratio of the comparison of non-performing financing to the amount of total financing. In addition, NPF is also an indicator of non-performing financing as seen from its fluctuating and uncertain nature (Rahman \& Fatmawati, 2020). The level of non-performing financing that is out of the limit will cause disruption to the profits of Islamic banks. It may force the operations of Islamic banks to stop due to several factors both from microeconomics and macroeconomics (Permataningayu \& Mahdaria, 2020). Therefore, the determinants that affect the financial performance of Islamic Commercial Banks in Indonesia are used as the theme of this research.

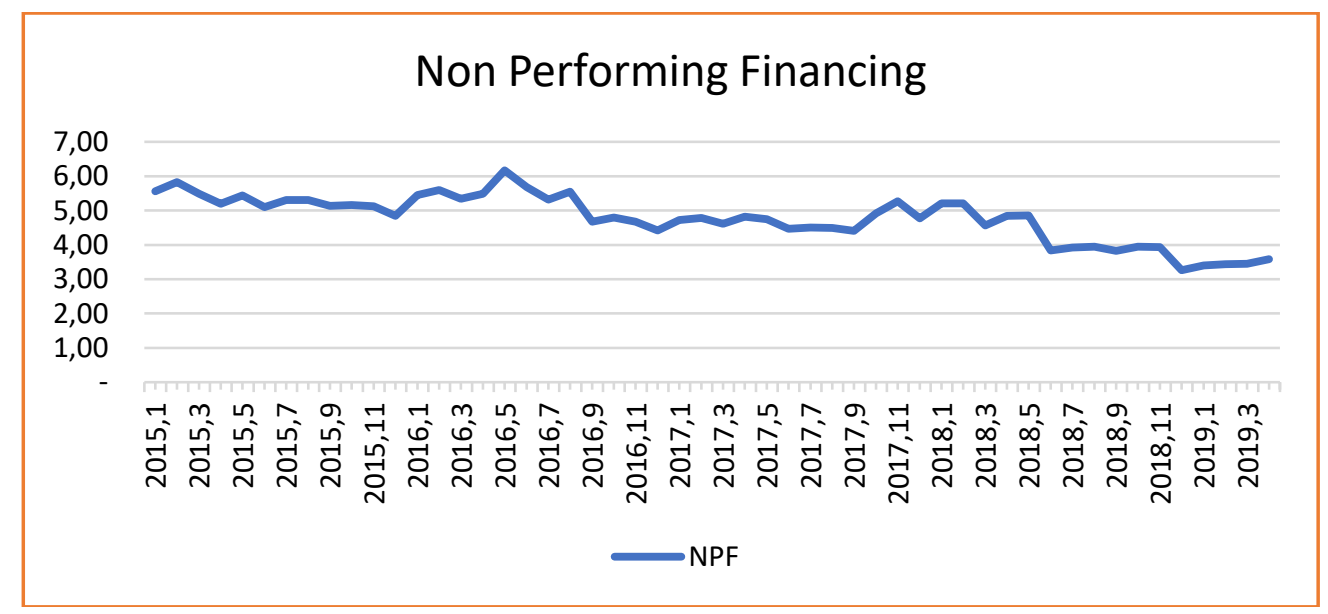

Figure 1. Non-Performing Financing of Islamic Commercial Bank in Indonesia (\%)

The development of NPF for the period January 2015 to April 2019 shows the growth in the ratio of non-performing financing experienced a significant increase in the period of the 5 th month of 2016, the NPF level was $6.17 \%$ in Islamic Commercial Banks. Hence, it can be concluded that the NPF rate has exceeded the maximum limit of the Bank Indonesia regulation, which is $5 \%$. This is due to the increase in public confidence in the distribution of funds to Islamic banks in the previous period. However, in the next period until the 4th month of 2019, there was a fluctuating decline.

Previous researchers such as Supriani and Sudarsono (2018), conducted a research on the influence of microeconomic and macroeconomic variables toward NPF in Indonesian Islamic banking. The results of the data analysis showed that in the short term the CAR variable has a negative and insignificant effect, while the FDR, ROA, BOPO and BI Rate variables have a significant positive effect on NPF. However, other variables such as inflation and exchange rates have a significant negative effect. In the short term, the CAR, FDR and BOPO variables have a significant positive effect on NPF, while ROA, BI Rate and Exchange Rate variables have a positive and insignificant effect on NPF. Lastly, the inflation variable has a negative and significant effect on NPF.

Meanwhile, Popita's Research, in this study, examined all Islamic Commercial Banks in Indonesia. This study used the quarterly financial reports of Islamic Commercial Banks in Indonesia with a purposive sampling technique. The results of this study indicate that the growth of real GDP 
and FDR have a positive yet insignificant effect on NPF, while inflation, SWBI, RR have a negative yet insignificant effect on NPF. Total assets have a negative and significant effect on NPF (Popita, 2013).

Several previous researchers have conducted research on the factors that affect NPF in Islamic Commercial Banks. In this study, eight variables were identified, namely CAR, FDR, BOPO, ROA, IPI, BI Rate, Inflation and SBIS (Firdaus, 2015; Amelia, 2019; Sari \& Amran, 2019). Research on the determinants of NPF is still being carried out in various countries. This is conducted because the NPF ratio can also measure the ability of banks to allocate and overcome credit risks that arise in Islamic bank (Cahyati, 2018; Nugrohowati \& Bimo, 2019

In the NPF factors, there are several important things that must be researched by banks. It is intended that it can be used as a reference in managing and overcoming risks that arise in nonperforming financing. Based on the background description, this study was conducted to identify the determinants that affect non-performing financing using microeconomic variables (CAR, FDR, BOPO, ROA) and macroeconomic variables (IPI, BI Rate, Inflation and SBIS). All of these variables are determinants of factors that result in non-performing financing. Hence, this research will be very useful for the banking sector, Bank Indonesia and the Government in making feasible and effective policies to be implemented in Islamic banking in Indonesia.

\section{Research Method}

The research was conducted using the quantitative method regarding Islamic Commercial Banks in Indonesia from January 2015 to April 2019. The data in the study were secondary data obtained from several agencies such as OJK (Financial Services Authority), BI (Bank Indonesia), BPS (Central Statistics Agency) as well as IFS (International Financial Statistics). The data is published and updated every month so that each year there will be a clear picture of Islamic financial data. The variables in this study consist of NPF as the dependent variable and CAR, FDR, BOPO, ROA, IPI, BI Rate, Inflation, and SBIS as the independent variables. The data obtained based on monthly data with the aim of data density to be able to represent the object of research and data variation on each variable can be minimized. NPF, CAR, FDR, BOPO, ROA and SBIS data are obtained from Islamic banking statistical reports through the official website of the Financial Services Authority (OJK). In addition, BI Rate data is obtained from the official website of Bank Indonesia (BI), inflation data is obtained from the official website of the Central Statistics Agency (BPS) and IPI data is obtained from the official website of the International Financial Statistics (IFS) for the period of 2015.1 to 2019.4.

This study uses the auto-regressive distributed lag (ARDL) data analysis technique. The ARDL analysis has several regression steps. The first step is to plot each data and then perform a stationary test analysis. The next step is a cointegration analysis using the Bounds Testing Cointegration method. This method represents a long-term ARDL approach with consistent estimatation that are asymptotically normal (Pesaran et al, 2001). The analytical tool used is the ARDL technique by EViews 10. The ARDL model is a model in which there are independent variables in the previous period, both the previous period and the relationship with the previous period listed in the regression analysis. The independent variable contained in the ARDL model responds to the dependent variable with a certain time lag in each variable.

\section{Dependent Variable}

\section{Non-Performing Financing (NPF)}

NPF is the ratio between total non-performing financing and total distribution of funds in the form of percentage. The lower the NPF ratio, the lower the level of non-performing financing (Rosidah, 2017; Sari \& Amran, 2019). NPF is also a loan in which there are problems in making repayments or there is a possibility of failure of the customer to pay his obligations. This is caused by external factors that are beyond the control of the debtor. Credit risk accepted by banks is one form of business risk. The higher the level of the NPF ratio, it will give a bad impact on Islamic banks (Poetry \& Sanrego, 2011). The impact can be in the form of losses which will lower the soundness 
of Islamic banks, and vice versa. If the NPF ratio is at a low level, the profits obtained by the bank will increase (Firmansari \& Suprayogi, 2015).

\section{Independent Variables}

\section{Capital adequacy ratio (CAR)}

CAR is a ratio that shows the interactions that occur in all Islamic bank assets that contain risks including credit, investment, securities, interbank bills where the risk is financed by standalone bank-owned capital funds out of its external sources such as public funds, loans (debt) and others (Firdaus, 2015). In addition, CAR is also said to be an indicator in assessing a bank's ability to cope with decreasing assets caused by various bank losses through risky assets. A higher CAR level will lead to a better bank's ability to manage and to bear the risk of any earning assets that have high risk in the financing system of Islamic Commercial Banks (Atiqoh, 2014; Amelia, 2019).

H1: CAR has a positive effect on NPF

\section{Financial to deposits ratio (FDR)}

FDR is the ratio between the financing that banks distribute to customers through third party funds. FDR will display the results of the Islamic bank's ability level in distributing the collected third party funds (Sari \& Amran, 2019). FDR is also able to influence the NPF value through fluctuations in third party funds. In macroeconomics, it can affect the operational performance of banks in determining policy making related to bank's financial performance (Amelia, 2019). If a bank has a good FDR as stipulated by the provisions of Bank Indonesia, the Islamic bank shows that the available funds can be used optimally for financing distribution to productive assets.

H2: FDR has a positive effect on NPF

\section{Operational efficiency ratio (BOPO)}

$\mathrm{BOPO}$ is the ratio of operational expenses to the operational income for the the last twelve months. Bank Indonesia gives a score of 100 on the soundness of Islamic Commercial Banks, if the bank reaches $\mathrm{BOPO}$ at $80 \%$. The BOPO ratio is closely related to the operational activities of Islamic banks. A high ratio of $\mathrm{BOPO}$ will not generate profits for Islamic banks. High income of Islamic banks will suppress the BOPO ratio due to low operational costs. Therefore, Islamic banks are in a soundness condition where non-performing financing falls into a low category (Auliani \& Syaichu, 2016).

H3: BOPO has a positive effect on NPF

\section{Return on assets (ROA)}

ROA is a level of ability of an Islamic bank to gain benefits in various bank's operational activities by utilizing its funds. The main objective of the bank is to achieve the maximum level of profitability (Supriani \& Sudarsono, 2018). ROA is usually used to measure the effectiveness and the efficiency of Islamic banks to generate high profits through the financing distribution system. Therefore, banks really need ROA information to set up a good financing distribution system. The impact of ROA on NPF depends on how management optimizes the available funds on Islamic banks. It can be said that a higher level of ROA will lead to a better ability of banks to generate profits from its funds (Tumewang et al., 2019).

H4: ROA has a negative effect on NPF

\section{Industrial production indeks (IPI)}

IPI is used to replace GDP because of the data used should be monthly. A high level of domestic output shows that there is an increase in the economic rate (Widarjono, 2020). This can also improve the performance of Islamic banks in managing financing distribution. Therefore, it is 
important for Islamic banks to see an external or macroeconomic perspective through the IPI level. The use of IPI is still not as wide as the use of real GDP, but IPI reflects economic growth on a monthly basis. In the developed countries, IPI is often used because they see that the monthly growth is more representative than the real GDP.

H5: IPI has a positive effect on NPF

\section{BI Rate}

BI Rate is the interest rate issued by Bank Indonesia. The BI Rate reflects the monetary policy stance set by the central bank. In the NPF, the BI Rate has a very influential relationship and cannot be separated from the contract used in Islamic bank financing (Supriani \& Sudarsono, 2018), This is stated in the financing under a profit-sharing agreement that depends on the profit/loss of the debtor. When a loss occurs, the Islamic bank will bear the risk of loss with the debtor (Aryani et al, 2016). The BI Rate can affect the increase in loan interest rates so that it can increase nonperforming financing that is borne by Islamic banks.

H6: BI Rate has a positive effect on NPF

\section{Inflation}

Inflation is an increase in the general price level that occurs directly and continuously from time to time that occurs in the economy. In addition, inflation is also a growth in the amount of money that is already above the growth rate of the real sector (Firdaus, 2015). This is due to the decreasing purchasing power of the currency and an excessive increase in borrowing will cause a default. Therefore, Islamic banks must be more alert in dealing with this issue in managing on the financing system (Rahmawulan, 2008).

H7: Inflation has a negative effect on NPF

\section{Bank Indonesia Sharia Certificate (SBIS)}

SBIS is used by Islamic banking for distribution of funds which can assist the government in helping the central bank to control the money supply. The reduced amount of money in circulation will lead to the less distribution of funding and financing available to Islamic banks (Auliani \& Syaichu, 2016). This can give a positive impact on Islamic banks, because there is no burden on financing. Thus, non-performing financing can be reduced and can provide a positive soundness to Islamic banks. H8: SBIS has a positive effect on NPF

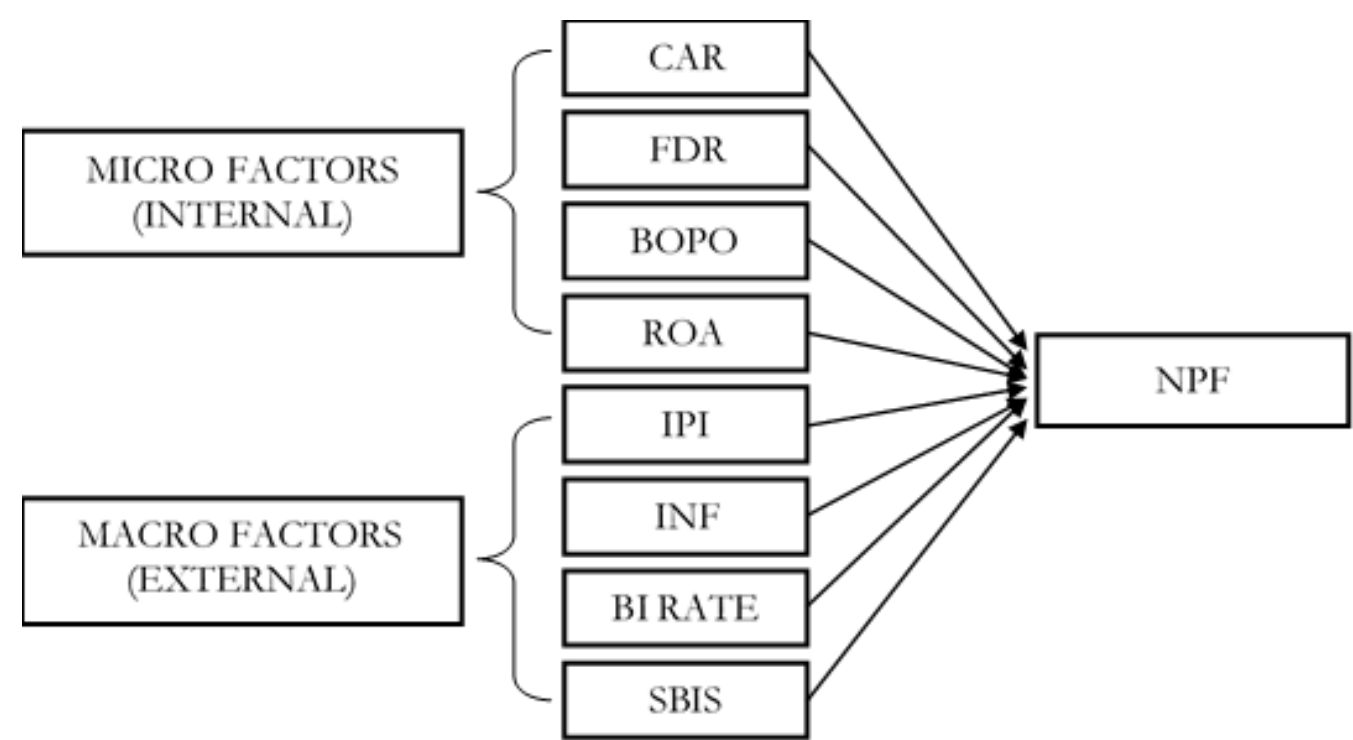

Figure 2. Theoretical Framework: Influencing Factors 
Table 1. Variables, Hypothesis and Data Sources Description

\begin{tabular}{llcl}
\hline \multicolumn{1}{c}{ Variables } & \multicolumn{1}{c}{ Description } & Hypothesis & Sources \\
\hline $\begin{array}{ll}\text { Dependent } \\
\text { NPF }\end{array}$ & Non-Performing Financing (\%) & & \\
Independent & & & OJK \\
CAR & Capital Adequacy Ratio (\%) & + & OJK \\
FDR & Financing to Deposit Ratio (\%) & + & OJK \\
BOPO & Operational Efficiency Ratio (\%) & + & OJK \\
ROA & Return On Asset (\%) & - & OJK \\
Macroeconomics & & + & IFS \\
IPI & Industrial Production Index (\%) & + & BPS \\
INF & Inflation Rate (\%) & + & BI \\
BI Rate & Bank Interest Rate (\%) & + & OJK \\
SBIS & Bank Indonesia Sharia Certificate (Rupiah) & +
\end{tabular}

Note: OJK (Financial Services Authority), IFS (International Financial Statistics), BPS (Central

Statistics Agency), and BI (Bank Indonesia).

In estimating the ARDL model, Ordinary Least Square (OLS) can be used to determine the ARDL order first. OLS application can be done if OLS assumptions are met in relation to the econometric basis. An estimation model that meets the Best Linear Unbiased Estimator (BLUE) is a prerequisite for the analysis base model (Widarjono, 2009). The ARDL model that is not biased, linear in the estimator results, and has a minimum variant will be more acceptable for a good ARDL model regression test. In addition, some OLS assumption problems can be tested through multicollinearity heteroscedasticity, and autocorrelation tests. This test is important to prevent the OLS assumption violations. In research, it is very important to avoid some classical assumptions for the sake of feasibility of a regression analysis model that is in accordance with ARDL.

\section{Result and Discussion}

\section{Results of the Unit Root Test for ADF and PP Methods}

Table 2 shows the descriptive statistics of the variables in the study. The average of each variable data value is greater than the standard deviation value in the data. This shows the tendency lies in the variable mean, as shown in the average value higher than the standard deviation value. The average value of the NPF variable shows $4.78 \%$ which is greater than the standard deviation value of 0.69. This shows that the ratio of non-performing financing in Islamic Commercial Banks will be well resolved by the savings they have. The average CAR value of $16.88 \%$ is also relatively safe, which shows the average CAR value is above the standard deviation value of $2.26 \%$. CAR with a minimum value of $14.09 \%$ indicates that Islamic Commercial Banks are able to provide good financing. This is due to the increase in production sharing contracts compared to other types of financing. (Azmat et al, 2015).

Table 2. Statistical Description

\begin{tabular}{lccccc}
\hline & N & Mean & Std. Deviation & Maximum & Minimum \\
\hline NPF & 35 & 4.78 & 0.69 & 6.17 & 3.26 \\
CAR & 35 & 16.88 & 2.26 & 21.39281 & 14.09 \\
FDR & 35 & 84.06 & 4.75 & 92.56 & 77.52 \\
BOPO & 35 & 93.40 & 3.35 & 99.04 & 86.95 \\
ROA & 35 & 0.89 & 0.347689269 & 1.52 & 0.16 \\
IPI & 35 & 135.81 & 8.828296558 & 156.78 & 119.67 \\
BIRATE & 35 & 5.81 & 1.23458634 & 7.75 & 4.25 \\
INFLATION & 35 & 0.26 & 0.320645559 & 0.97 & -0.45 \\
SBIS & 35 & $5,539.53$ & 1407.917166 & 8,825 & 3,385 \\
\hline
\end{tabular}


The average value of FDR is $84.06 \%$ with a standard deviation of 4.75 . The average FDR illustrates that the FDR ratio for the period of 2015.1 to 2019.4 is still very good, seen from the average FDR which is between $85 \%-110 \%$. The average value of BOPO shows $93.4 \%$, with a value of $86.95 \%$ illustrating that Islamic Commercial Banks allocate funds to operational expenses well. The ROA variable shows an average value of $0.89 \%$ with a standard deviation of 0.35 . Then the average ROA value indicates that the rate of return on assets in the period of 2015.1 to 2019.4 in Islamic Commercial Banks does not experience problems, in other words, it is still within reasonable limits. The IPI average value of $135.81 \%$ indicates a number greater than the minimum value of 119.67. IPI is the value taken from the production output in each month, in other words it can reflect the annual GDP value from the perspective of the production index.

Apart from IPI, there are other macroeconomic variables, namely the BI Rate, the Inflation and the SBIS. The average value of the BI Rate is $5.81 \%$ with a standard deviation of 1.23 . The minimum BI Rate value of $4.25 \%$ means that the BI Rate for the period of 2015.1 to 2019.4 shows a trigger caused by the large increase in financing onIslamic banks. The high BI Rate can significantly increase consumption and financing. Inflation for the period of 2015.1 to 2019.4 shows an average value of $0.26 \%$, which means that it is still very safe for various economic activities to be carried out, such as profit-sharing financing at Islamic Commercial Banks. The SBIS average value is 5,540, which means that the SBIS allocation is quite good in helping BI stabilize monetary policy.

Before estimating the ARDL model, a stationarity test was carried out on each variable in order to determine the feasibility level of the variable. Table 3 presents the results of the regression on the stationarity test using the ADF and PP method. The two tests are applied at a constant level and a constant rate and trend. The results show that the inflation variable is stationary at the level, where the ADF value > Test Critical Values. Meanwhile, the results of other variables such as NPF, CAR, FDR, BOPO, ROA, IPI, BI Rate and SBIS are not stationary at this level. Then the results obtained from the stationarity test state that most of the above variables are stationary at I (1), but only one variable is stationary at I (0).

Then, the results of the NPF, CAR, FDR, BOPO, ROA, IPI, BI Rate and SBIS variables are stationary in the First difference, where on the seven variables the ADF value $>$ Test Critical Values. In addition, using the PP method, the unit root test resulted in stationary inflation and IPI at the level, where PP > Test Critical Values. While the results at the First difference level are all stationary variables such as NPF, CAR, FDR, BOPO, ROA, IPI, BI Rate and SBIS are stationary where PP $>$ Test Critical Values. Then it shows the variables experiencing problems at the unit root obtained from the significant level at the First difference level for several variables such as NPF, CAR, FDR, BOPO, ROA, IPI, BI Rate and SBIS both in the ADF and PP methods.

Table 3. Unit Root Result: ADF and PP

\begin{tabular}{lcrrrrrrr}
\hline & \multicolumn{4}{c}{ LEVEL } & \multicolumn{3}{c}{ First Difference } \\
\cline { 2 - 10 } & \multicolumn{2}{c}{ Constant } & \multicolumn{3}{c}{$\begin{array}{c}\text { Constant and } \\
\text { Trend }\end{array}$} & \multicolumn{2}{c}{ Constant } & \multicolumn{3}{c}{$\begin{array}{c}\text { Constant and } \\
\text { Trend }\end{array}$} \\
\cline { 2 - 11 } & ADF & \multicolumn{1}{c}{ PP } & \multicolumn{1}{c}{ ADF } & PP & ADF & PP & ADF & PP \\
\hline NPF & -1.22 & -1.29 & -3.14 & $-3.32^{* * *}$ & $-3.20^{* *}$ & $-9.56^{*}$ & $-3.21^{* * *}$ & $-9.47^{*}$ \\
CAR & -0.78 & -0.79 & -2.11 & -2.21 & $-6.90^{*}$ & $-6.90^{*}$ & $-6.83^{*}$ & $-6.83^{*}$ \\
FDR & -0.84 & -0.74 & -2.55 & -2.54 & $-9.07^{*}$ & $-9.06^{*}$ & $-8.96^{*}$ & $-8.96^{*}$ \\
BOPO & -0.86 & -0.73 & -3.12 & $-3.10^{* *}$ & $-7.80^{*}$ & $-7.80^{*}$ & $-7.89^{*}$ & $-7.89^{*}$ \\
ROA & -1.70 & -1.59 & $-3.67^{* *}$ & $-3.71^{* *}$ & $-9.20^{*}$ & $-9.23^{*}$ & $-9.21^{*}$ & $-9.25^{*}$ \\
IPI & -1.86 & $-2.81^{* * *}$ & $-7.59^{*}$ & $-9.12^{*}$ & $-11.95^{*}$ & $-34.09^{*}$ & $-11.82^{*}$ & $-34.00^{*}$ \\
BIRATE & -1.40 & -1.60 & -0.08 & -0.47 & $-5.14^{*}$ & $-5.26^{*}$ & $-5.44^{*}$ & $-5.50^{*}$ \\
INFLATION & $-6.87^{*}$ & $-6.41^{*}$ & $-4.78^{*}$ & $-7.93^{*}$ & $-7.73^{*}$ & $-11.95^{*}$ & $-7.61^{*}$ & $-12.12^{*}$ \\
SBIS & -2.17 & -1.77 & -2.34 & -1.91 & $-4.83^{*}$ & $-4.81^{*}$ & $-4.80^{*}$ & $-4.77^{*}$ \\
\hline Note: Significance Level $(*)=\alpha 1 \%,(* *)=\alpha 5 \%$, and $(* * *)=\alpha 10^{*} \%$. & & &
\end{tabular}


Estimation Result of ARDL, Autocorrelation Test and Heteroscedasticity Test

Table 4. Estimation Result of ARDL

\begin{tabular}{|c|c|c|c|}
\hline \multirow[t]{2}{*}{ Variable } & \multicolumn{3}{|c|}{ NPF } \\
\hline & Coefficient & t-value & Prob* \\
\hline $\mathrm{C}$ & $-79.4523^{*}$ & -4.59152 & 0.0025 \\
\hline NPF(-1) & 0.259023 & 1.250816 & 0.2512 \\
\hline NPF(-2) & -0.213483 & -1.21499 & 0.2638 \\
\hline $\operatorname{NPF}(-3)$ & -0.00074 & -0.00371 & 0.9971 \\
\hline $\mathrm{NPF}(-4)$ & -0.208837 & -1.22304 & 0.2609 \\
\hline CAR & 0.070344 & 0.803414 & 0.4482 \\
\hline CAR(-1) & 0.076925 & 0.586756 & 0.5758 \\
\hline CAR $(-2)$ & -0.129982 & -0.89468 & 0.4007 \\
\hline CAR $(-3)$ & -0.239625 & -1.67447 & 0.1379 \\
\hline CAR (-4) & 0.208686 & 1.565105 & 0.1615 \\
\hline FDR & -0.070624 & -1.32934 & 0.2254 \\
\hline $\operatorname{FDR}(-1)$ & $0.184377 * *$ & 2.685187 & 0.0313 \\
\hline $\operatorname{FDR}(-2)$ & 0.038488 & 0.718894 & 0.4955 \\
\hline FDR(-3) & $-0.273299 *$ & -3.30694 & 0.013 \\
\hline FDR $(-4)$ & $-0.125767 * * *$ & -2.0864 & 0.0754 \\
\hline $\mathrm{BOPO}$ & $0.310453^{* *}$ & 2.766738 & 0.0278 \\
\hline $\mathrm{BOPO}(-1)$ & $0.309315^{* *}$ & 3.127483 & 0.0167 \\
\hline $\mathrm{BOPO}(-2)$ & -0.135719 & -1.10638 & 0.3051 \\
\hline $\mathrm{BOPO}(-3)$ & $0.307694 * *$ & 2.857717 & 0.0244 \\
\hline $\mathrm{BOPO}(-4)$ & $0.299157 *$ & 3.347392 & 0.0123 \\
\hline $\mathrm{ROA}$ & $2.766696^{*}$ & 3.359553 & 0.0121 \\
\hline $\operatorname{ROA}(-1)$ & $1.928917 * *$ & 2.806211 & 0.0263 \\
\hline $\mathrm{ROA}(-2)$ & $-1.489137^{*}$ & -1.66957 & 0.1389 \\
\hline $\operatorname{ROA}(-3)$ & 0.174614 & 0.257419 & 0.8043 \\
\hline $\mathrm{ROA}(-4)$ & $3.563705^{*}$ & 4.641324 & 0.0024 \\
\hline IPI & -0.015868 & -1.28629 & 0.2392 \\
\hline BIRATE & 0.394613 & 1.537897 & 0.168 \\
\hline BIRATE(-1) & $-1.713062^{*}$ & -3.27751 & 0.0135 \\
\hline BIRATE(-2) & $1.202723^{* *}$ & 3.042242 & 0.0188 \\
\hline BIRATE(-3) & 0.091928 & 0.330466 & 0.7507 \\
\hline BIRATE(-4) & 0.256726 & 0.781806 & 0.46 \\
\hline INFLATION & $-0.93781 *$ & -3.86722 & 0.0062 \\
\hline INFLATION(-1) & -0.042166 & -0.23829 & 0.8185 \\
\hline INFLATION(-2) & $-0.436139 * *$ & -2.66698 & 0.0321 \\
\hline INFLATION(-3) & -0.023129 & -0.13431 & 0.8969 \\
\hline INFLATION(-4) & $-0.419287 * * *$ & -2.14355 & 0.0693 \\
\hline SBIS & $-0.00066^{*}$ & -4.69692 & 0.0022 \\
\hline $\operatorname{SBIS}(-1)$ & $0.000704^{*}$ & 3.437894 & 0.0109 \\
\hline $\operatorname{SBIS}(-2)$ & -0.000281 & -1.69872 & 0.1332 \\
\hline $\operatorname{SBIS}(-3)$ & $-4.06 \mathrm{E}-05$ & -0.29153 & 0.7791 \\
\hline SBIS(-4) & 0.000152 & 1.162764 & 0.283 \\
\hline $\mathrm{R}^{2}$ & 0.992694 & & \\
\hline Diagnostic & & & \\
\hline LM 1 & 0.8020 & 0.9322 & \\
\hline LM 2 & 0.0000 & 0.0176 & \\
\hline ARCH 1 & 0.4747 & 0.4855 & \\
\hline ARCH 2 & 0.1559 & 0.1634 & \\
\hline
\end{tabular}


The next step in conducting ARDL regression analysis is to estimate using the Akaike Info Criterion (AIC) method with a maximum lag length of 4 for estimating the ARDL model (Widarjono, 2018). Table 4 is a combined table of two parts which explains the results of the ARDL estimation at the top. In addition, the lower part shows the results of the estimation on the autocorrelation test with the Lagrange Multiplier (LM) test method at lag 1 (LM1) and lag 2 (LM2), as well as the heteroscedasticity test using the Autoregressive Conditional Heteroscedasticity (ARCH) method with lag 1 (ARCH1) and lag 2 (ARCH2).

The ARDL estimation results show the lag length of ARDL (4,4,4,4,4,0,4,4,4). From the 40 independent variables, there are 18 independent variables that have a significant effect on $\alpha 10 \%$ or less than $\alpha 10 \%$. Meanwhile, the results of the LM (1) and LM (2) tests as well as the ARCH (1) and ARCH (2) tests show that there are no problems with autocorrelation and the data problem has heteroscedasticity. Then the ARDL model can be continued at the next stage, namely testing the cointegration in the model.

\section{Bound Test Cointegration}

In this study, cointegration testing was carried out using the Bound Testing Approach method. This method is used to determine the long-term relationship between variables in the model equation. In addition, cointegration can also be used as an analytical tool in overcoming nonstationary time series data (Supriani \& Sudarsono, 2018). Table 5 presents the results of the Bound Test Cointegration at the top showing the critical $F$ value based on the $F$ distribution developed by Pesaran (2001). Then the critical value has an upper limit of 1 (1) and a lower limit of 1 (0). Table 5 shows the results where the F-Statistic Value $>$ the value of $1(0)$ and 1 (1), which is $5.495983>1.85$ and 2.85 , thus $\mathrm{H} 0$ is rejected. Therefore, it can be concluded that the data on each variable has a cointegration value which indicates a long-term balance, as well as NPF, CAR, FDR, BOPO, ROA, IPI, BI RATE, Inflation and SBIS show a stationary value.

Table 5. Bound Test Cointegration Results

\begin{tabular}{ccc}
\hline F-Statistic Value & & 5.495983 \\
\hline Significance & 10 Bound (Lower Bound) & 11 Bound (Upper Bound) \\
$10 \%$ & 1.85 & 2.85 \\
$5 \%$ & 2.11 & 3.15 \\
$2.5 \%$ & 2.33 & 3.42 \\
$1 \%$ & 2.62 & 3.77 \\
\hline
\end{tabular}

\section{Final Result of Auto-Regressive Distributed Lag (ARDL)}

The optimal lag combination in choosing the best ARDL model can be tested through the Akaike Info Criterion (AIC) selection method. From the regression results, it is found that the values of R-Squared Adjusted and R-Squared have relatively high values (0.95 and 0.99$)$, meaning that $95 \%$ and $99 \%$ of the variation of the NPF variable can be explained by each of the selected ARDL model independent variables. Long-term conditions in the ARDL model are the main analysis performed in the regression of non-performing financing of Islamic bank. Table 7 presents the results of the estimated long-term coefficient, t-value and prob in the ARDL model. Meanwhile, Table 6 presents the estimation results of the short-term coefficients, $t$-values and probability in the ARDL model.

Table 6 shows the results of the short-term estimation in which the FDR, inflation and SBIS variables have a negative and significant effect on NPF. Meanwhile, other variables such as BOPO, ROA, IPI, BI Rate produce estimated values that have a positive and significant effect on NPF. However, only CAR produces insignificant value in the short-term. So there are several causes and effects that support this study from the results of previous studies. Thus the research 
results will be more relevant and understandable. The short-term ARDL ECM results listed in table 6 obtain a CointEq (-1) value which is negative and significant. The result of the CointEq value (1 ) is -1.164037 with a probability value of 0.0000 which is significant for alpha. Then these results give the meaning that the ARDL ECM model is valid.

Table 6. Short-Term Estimation Results

\begin{tabular}{|c|c|c|c|}
\hline \multirow[t]{2}{*}{ Variable } & \multicolumn{3}{|c|}{ NPF } \\
\hline & Coefficient & t-value & Prob* \\
\hline $\mathrm{D}(\mathrm{NPF}(-1))$ & $0.42306^{*}$ & 4.506906 & 0.0028 \\
\hline $\mathrm{D}(\mathrm{NPF}(-2))$ & $0.209577 * *$ & 2.564183 & 0.0373 \\
\hline $\mathrm{D}(\mathrm{NPF}(-3))$ & $0.208837^{* *}$ & 3.092955 & 0.0175 \\
\hline $\mathrm{D}(\mathrm{CAR})$ & 0.070344 & 1.658612 & 0.1412 \\
\hline $\mathrm{D}(\mathrm{CAR}(-1))$ & $0.160921^{* *}$ & 3.001959 & 0.0199 \\
\hline $\mathrm{D}(\mathrm{CAR}(-2))$ & 0.03094 & 0.62499 & 0.5518 \\
\hline $\mathrm{D}(\mathrm{CAR}(-3))$ & $-0.208686^{*}$ & -3.86825 & 0.0061 \\
\hline $\mathrm{D}(\mathrm{FDR})$ & $-0.070624^{*}$ & -3.55714 & 0.0093 \\
\hline $\mathrm{D}(\mathrm{FDR}(-1))$ & $0.360579 *$ & 8.692578 & 0.0001 \\
\hline $\mathrm{D}(\mathrm{FDR}(-2))$ & $0.399067 *$ & 8.484125 & 0.0001 \\
\hline $\mathrm{D}(\mathrm{FDR}(-3))$ & $0.125767^{*}$ & 4.313752 & 0.0035 \\
\hline $\mathrm{D}(\mathrm{BOPO})$ & $0.310453^{*}$ & 7.669448 & 0.0001 \\
\hline $\mathrm{D}(\mathrm{BOPO}(-1))$ & $-0.471132^{*}$ & -5.95707 & 0.0006 \\
\hline $\mathrm{D}(\mathrm{BOPO}(-2))$ & $-0.606851^{*}$ & -8.74973 & 0.0001 \\
\hline $\mathrm{D}(\mathrm{BOPO}(-3))$ & $-0.299157 *$ & -6.94169 & 0.0002 \\
\hline $\mathrm{D}(\mathrm{ROA})$ & $2.766696^{*}$ & 8.758153 & 0.0001 \\
\hline $\mathrm{D}(\mathrm{ROA}(-1))$ & $-2.249182 *$ & -4.80496 & 0.002 \\
\hline $\mathrm{D}(\mathrm{ROA}(-2))$ & $-3.738319 *$ & -7.72253 & 0.0001 \\
\hline $\mathrm{D}(\mathrm{ROA}(-3))$ & $-3.563705^{*}$ & -9.69523 & 0.0000 \\
\hline D(BIRATE) & $0.394613^{*}$ & 3.341264 & 0.0124 \\
\hline D(BIRATE(-1)) & $-1.551377 *$ & -8.85808 & 0.0000 \\
\hline D(BIRATE(-2)) & $-0.348654 * *$ & -2.95046 & 0.0214 \\
\hline D(BIRATE(-3)) & $-0.256726^{* *}$ & -2.34886 & 0.0512 \\
\hline D(INFLATION) & $-0.93781 *$ & -10.898 & 0.0000 \\
\hline D(INFLATION(-1)) & $0.878554^{*}$ & 8.22974 & 0.0001 \\
\hline D(INFLATION(-2)) & $0.442416^{*}$ & 5.411631 & 0.001 \\
\hline D(INFLATION(-3)) & $0.419287 *$ & 5.104304 & 0.0014 \\
\hline $\mathrm{D}(\mathrm{SBIS})$ & $-0.00066^{*}$ & -11.1991 & 0.0000 \\
\hline $\mathrm{D}(\mathrm{SBIS}(-1))$ & $0.00017^{*}$ & 3.711678 & 0.0075 \\
\hline $\mathrm{D}(\mathrm{SBIS}(-2))$ & $-0.000111^{* * *}$ & -2.24094 & 0.06 \\
\hline $\mathrm{D}(\mathrm{SBIS}(-3))$ & $-0.000152^{* *}$ & -2.9451 & 0.0216 \\
\hline CointEq(-1)* & $-1.164037 *$ & -11.2081 & 0.0000 \\
\hline $\mathrm{R}^{2}$ & 0.971775 & & \\
\hline DW & 1.964841 & & \\
\hline
\end{tabular}

In the estimation results, ARDL provides information that in the short-term, CAR is not significant for NPF. From 2015.1 to 2019.4, the CAR value seems relatively stable. Therefore, from 
these results, it can be concluded that the management of Islamic banks can manage the collected capital which is used to overcome several problems with bank capital risks. Therefore, in the short and long-term CAR has no direct effect on the NPF level. This is also due to the easier management of the CAR level already regulated by the OJK. These results were also found in Purnamasari and Musdholifah (2018), Haifa and Wibowo (2015), and Firdaus (2015).

The ARDL estimation results on the FDR variable in the short and long-term show a significant negative effect on NPF. Inflation in the short and long-term also has a significant negative effect. Both of these are supported by several studies which say that FDR and inflation have a negative effect which can help Islamic banks to avoid losses on problem financing. Meanwhile, other variables such as BOPO, ROA, BI Rate and SBIS in the short-term have a significant positive effect on NPF. Therefore, the same as previous studies, these four variables have a significant positive effect on NPF. So it can be concluded that non-performing financing will be handled properly by Islamic banks through organized financing.

Table 7. Long-Term Estimation Results

\begin{tabular}{lrcc}
\hline \multirow{2}{*}{ Variable } & \multicolumn{3}{c}{ NPF } \\
\cline { 2 - 4 } & Coefficient & t-value & Prob* \\
\hline C & $-68.25585^{*}$ & -3.83468 & 0.0064 \\
CAR & -0.011729 & -0.10869 & 0.9165 \\
FDR & $-0.212044^{*}$ & -3.39584 & 0.0115 \\
BOPO & $0.93717 *$ & 4.520804 & 0.0027 \\
ROA & $5.966131^{*}$ & 4.046788 & 0.0049 \\
IPI & -0.013632 & -1.25543 & 0.2496 \\
BIRATE & 0.200104 & 1.233363 & 0.2572 \\
INFLATION & $-1.596626^{*}$ & -3.0669 & 0.0181 \\
SBIS & -0.000109 & -1.29979 & 0.2348 \\
\hline Note: Significance Level $(*)=\alpha 1 \%,(* *)=\alpha 5 \%$, and $(* * *)=\alpha 10 \%$.
\end{tabular}

Table 7 presents the results of the estimation of the auto-regressive distributed lag (ARDL) method in the long-term. Looking from the table above, the values of CAR, IPI and BI Rate do not significantly influence NPF. Meanwhile, the FDR, inflation and SBIS resulted in a significant negative effect on NPF. Meanwhile, the BOPO and ROA estimates have a significant positive effect on NPF.

Table 7 shows the long-term estimation results in which CAR shows insignificant results for NPF (H1 accepted). This study is not in accordance with the results of previous studies of Asrini et al. (2018) and Atiqoh (2014) showing that there is a negative relationship between CAR and NPF. If the CAR is high, the value of the Risk-Weighted Assets (RWA) is low. This is because the low RWA will causea high non-performing financing. CAR also shows the level of the total amount of all assets that contain risk from the capital held for allocating the financing of Islamic banks. Hence, in this case the CAR will not affect the performance of Islamic banks in determining the financing system policy. In the long term, CAR will not affect NPF.

FDR shows that the estimation results in the long-term have a significant negative effect on NPF (H2 is rejected). These results are consistent with the research conducted by Auliani dan Syaichu (2016), Pradana (2018), and Rosidah (2017) which resulted in a significant negative relationship to NPF. When the amount of financing disbursed by Islamic banks increases, it is possible that the FDR ratio will also increase along with the increase in the distribution of funds. The more the amount of credit through the increase in financing by Islamic banks, it will have a side effect in the form of a quite high risk of financing.

From the long-term estimation results, BOPO shows a significant positive result on NPF (H3 accepted). In this study, it is in accordance with the research conducted by Atiqoh (2014), dan 
Adicondro (2015) which shows a significant positive relationship to NPF. If the BOPO shows a high number, the Islamic bank may be in a problematic position. A lower BOPO ratio will bring a financial soundness of Islamic bank. Looking from the high income with low operational costs. The condition of the bank experiencing problems is in the level of financing or NPF which is quite high.

Table 7 shows the ROA results which have a significant positive effect on the NPF level (H4 is rejected). This is in line with the results of research conducted by Cahyati (2018), Sholihatun (2014) dan Isnaini (2019), showing that ROA has a positive relationship to NPF. A higher level of ROA would help the management of financing distribution to identify the more risky financing conditions. However, ROA which has a positive effect means that existing banking assets are used for financing that generates profits for Islamic banks. Then this will further increase the level of profit of Islamic banks.

IPI shows that the long-term estimation results are not significant for NPF (H5 is rejected). This study contradicts previous research by Nasution and Ulum (2015), Nuryartono et al. (2016), and Ramadhan (2017) who said that the IPI variable had a significant negative effect on NPF. This is due to the large contribution of IPI in improving the financial economy through added value, employment and foreign exchange as well as national competitiveness. When the IPI increases, sales and income will also increase and result in an additional workforce as well as an increase in economic growth. In Islamic banking, this has an impact on reducing the provisions in financing. This condition results in an increase in the risk of non-performing financing in Islamic Commercial Banks. However, these results indicate that the IPI will not affect the NPF level of Islamic Commercial Banks in the long-term.

From the long-term estimation results, the BI Rate shows insignificant results for NPF (H6 is rejected). This is inversely proportional to the research by Najiatun et al. (2020) dan Setyowati (2019), showing that there is a relationship between the BI Rate and NPF. This relationship indicates a positive influence between the two things. In other words, there is a profit-sharing ratio for a good Islamic bank. Then it will lead to the achievement of a significant profit target for Islamic banks. However, the ARDL estimation results show that there is no significant long-term effect on NPF. So in the long-term, an increase in interest rates at the BI Rate will not result in an increase in the risk of non-performing financing.

Inflation in the long-term shows a significant negative effect on NPF (H7 accepted). This study is in accordance with the results of research by Setiawan and Bagaskara (2016), and Firmansyah (2015) showing results where there is a negative influence between inflation and NPF. The increase in inflation results in an increase in prices which makes prices relatively more expensive. This results in a reduction in the level of consumption and has an impact on the level of production. This relationship also has an impact on Islamic Commercial Banks which will cause a higher ratios and margins but a failure to pay the debt. Thus, inflation in the long term will result in a financing default.

The long-term ARDL estimation results on the SBIS variable show a negative effect on NPF (H8 is rejected). This is supported by the research conducted by Pareshkumar (2014) and Fadhilah and Sukmana (2017) where interest rates will have a negative effect on exchange rates. Then the increase in the value of SBIS would result in an increase in the difference between the existing domestic profit sharing and foreign profit sharing or interest rates. This interest rate results in a high rate of return on financial instruments or SBIS. Therefore, investors interested in investing and financing problems will have a high risk in Islamic banks.

\section{Conclusion}

From the results of the ARDL regression analysis, it can be concluded that in the short and long term the independent variables on macroeconomics and microeconomics show various effects. In the short term, the variables have a different effect on each lag. The ROA variable in the long and short term illustrates that there is a large influence compared to other variables on the NPF level. The 
estimation results of the ARDL model can be concluded that Islamic Commercial Banks in Indonesia have a deeper ability to overcome problems in the distribution of financing. So that this situation can protect Islamic Commercial Banks from excessive credit risk in the long term. In addition, with a stable inflation, it can also help Islamic Commercial Banks from various risks caused by financing problems.

This research is far from perfect, in other words, there are many weaknesses in this model. With the variation in the additional variables, it allows NPF to be more stable and the results are better. Besides, there are several macroeeconomic variables that can affect the NPF level. As with investment and productive financing provided from within the country and abroad.

\section{References}

Adicondro, Y.Y., \& Pagestuti, I.R.D. (2015). Analisis pengaruh pertumbuhan GDP, tingkat suku bunga, pertumbuhan ekspor, pertumbuhan kredit dan BOPO terhadap non performing loan pada bank umum di Indonesia tahun 2010 - 2014. Diponegoro Journal of Management, 4(4), 1-12. Retrieved from https://ejournal3.undip.ac.id/index.php/djom/article/view/13222/12780

Amelia, E.A. (2019). Pengaruh capital adequacy ratio (CAR), inflasi dan financing to feposit ratio (FDR) terhadap non performing financing (NPF) pada bank umum Syariah Periode 20152017. Jurnal Intelektualita: Keislaman, Sosial Dan Sains 8 (1), 11-18. https://doi.org/10.19109/intelektualita.v8i1.4223

Asrini, K.S., Suwendra, I. W., \& Suwarna. (2018). Pengaruh CAR, LDR dan bank size terhadap NPL pada lembaga perbankan yang terdaftar di bursa efek Indonesia. Bisma Jumal Manajemen, 4(1), 34-41. http://dx.doi.org/10.23887/bjm.v4i1.21977

Atiqoh, N. (2014). Pengaruh CAR, LDR, BOPO, inflasi dan GDP terhadap NPL bank konvensional. Universitas Bakrie Jakarta. Retrieved from https://media.neliti.com/media/publications/253299-none-e9e753a6.pdf

Auliani, M. M. \& Syaichu, M. (2016). Analisis pengaruh faktor internal dan faktor eksternal terhadap tingkat pembiayaan bermasalah pada bank umum Syariah di Indonesia periode tahun 2010-2014. Diponegoro Journal of Management, 5(3), 1-14. https://ejournal3.undip.ac.id/index.php/djom/article/view/14644

Azmat, S., Skully, M., \& Brown, K. (2015). Can Islamic banking ever become Islamic? Pacific Basin Finance Journal, 34, 253-272. https://doi.org/10.1016/j.pacfin.2015.03.001

Cahyati, A.I. (2018). Analisis pengarub LDR, CAR, BOPO, ROE dan ROA terhadap NPL/NPF pada perbankan di Indonesia, 1-12. Retrieved from https://dspace.uii.ac.id/handle/123456789/12641

Fadhilah, N., \& Sukmana, R. (2017). Pengaruh sertifikat bank Indonesia (SBIS), Jakarta Islamic index (JII), tingkat inflasi dan index harga saham gabungan (IHSG) terhadap nilai tukar: pendekatan autoregressive distributed lag (ARDL), Jumal Ekonomi Syariah Teori dan Terapan, 4(10), 833-846. https://doi.org/10.20473/vol4iss201710pp833-846

Firdaus, R. N. (2015). Pengaruh faktor internal dan eksternal yang mempengaruhi pembiayaan bermasalah pada bank umum syariah di Indonesia. El-Dinar, 3(1), 82-108. https://doi.org/10.18860/ed.v3i1.3339

Firmansari, D., \& Suprayogi, N. (2015). Pengaruh variabel makroekonomi dan variabel spesifik bank terhadap non performing financing pada bank umum Syariah dan unit usaha Syariah di Indonesia periode 2003-2014. Jurnal Ekonomi Syariah Teori dan Terapan, 2 (6), 512-520. https://doi.org/10.20473/vol2iss20156pp512-520 
Firmansyah, I. (2015). Determinant of non performing loan: The case of Islamic bank in Indonesia. Buletin Ekonomi Moneter dan Perbankan 17 (2), 241-258. https://doi.org/10.21098/bemp.v17i2.51.

Haifa \& Wibowo, D. (2015). Pengaruh faktor internal bank dan makro ekonomi terhadap non performing financing perbankan Syariah di Indonesia periode 2010. 01. Jurnal Nisbah, 1(2), 74- 87. http://dx.doi.org/10.30997/jn.v1i2.253

Isnaini, F., Sahara, S., \& Nursyamsiah, T. (2019). Faktor-faktor yang memengaruhi tingkat non performing financing dan non performing loan pada dual banking system di Indonesia. $\mathrm{Al}$ Muгara'ah, 7 (1), 47-59. https://doi.org/ 10.29244/jam.7.1.47-59.

Najiatun., Sanusi, M., Rahman, M. Herianingrum, S., (2020). Analisis variabel makroekonomi terhadap NPF perbankan Syariah di Indonesia. Jurnal Ekonomi 24 (3): 335-349. https://doi.org/10.24912/je.v24i3.597.

Nasution, Z., \& Ulum, A. S. (2015). Analisis risiko pembiayaan Syariah pada sektor ekonomi. Jurnal Kompilek, $\quad 7(2)$ : 110-122. $\quad$ Retrieved from https://journal.stieken.ac.id/index.php/kompilek/article/view/184

Nuryartono, N., Saptono, I. T., \& Was'an, G. A. (2016). Kaitan kondisi makroekonomi dengan non performing financing berdasarkan sektor ekonomi pada perbankan Syariah di Indonesia. Jurnal Keuangan dan Perbankan., 20(1): 104-115. Retrieved from https://media.neliti.com/media/publications/178793-ID-kaitan-kondisi-makroekonomidengan-non-p.pdf

Nugrohowati, R. N. I., \& Bimo, S. (2019). Analisis pengaruh faktor internal bank dan eksternal terhadap Non-Performing Financing (NPF) pada Bank Perkreditan Rakyat Syariah di Indonesia. Jurnal Ekonomi \& Keuangan Islam, 5(1), 42-49. https://doi.org/10.20885/jeki.vol5.iss1.art6

Permataningayu, G., \& Mahdaria, S. (2020). The effect of non-performing financing and financing to deposit ratio on Islamic banks financing in Indonesia. Asian Journal of Islamic Management, 1(1), 28-37. https://doi.org/10.20885/ajim.vol1.iss1.art3

Pesaran, M. H., Shin, Y., \& Smith, R. J. (2001). Bounds testing approaches to the analysis of level relation- ships. Journal of Applied Econometrics, 16(3), 289-326. https://doi.org/10.1002/jae.616

Poetry, Z. D. \& Sanrego, Y. D. (2011). Pengaruh variabel makro dan mikro terhadap NPL perbankan konvensional dan NPF perbankan Syariah. Islamic Fianance \& Business Review Journal, 6(2), 79-104. http://dx.doi.org/10.30993/tifbr.v6i2.53

Popita, M. S. A. 2013. Analisis penyebab terjadinya non performing financing pada bank umum Syariah di Indonesia. Accounting Analysis Journal, 2(4): 404-412. https://doi.org/10.15294/aaj.v2i4.2884

Purnamasari, A. E., \& Musdholifah, M. (2018). Analisis faktor eksternal dan internal bank terhadap risiko pembiayaan bank umum Syariah di Indonesia periode 2012-2015. Ilmu Manajemen, 4(2): 425-436. https://doi.org/10.26740/bisma.v9n1.p13-25

Pradana, M. N. R. (2018). Pengaruh likuiditas dan variabel eksternal terhadap non performing financing pada bank Syariah. Eksis, 13(2): 131-144. https://ejournal.stiedewantara.ac.id/index.php/001/issue/view\%0AHalaman

Rahman, T., \& Fatmawati, K. (2020). The influence of financial ratios on non perfroming financing of the sharia rural banks of Special Regions of Yogyakarta (BPRS DIY) period 2015-2018, Asian Journal of Islamic Management, 2(1), 25-35. https://doi.org/10.1108/AJIM.vol2.iss1.art3 
Ramadhan, P. (2017). Determinan pembiayaan bermasalah sektor pertambangan pada perbankan Syariah. Jurnal Akuntabilitas, 10(2): 368-390. https://doi.org/10.15408/akt.v10i2.6141

Rahmawulan, Y. (2008), Perbandingan faktor penyebab timbulnya NPL dan NPF pada perbankan Syariah dan konvensional di Indonesia. Thesis PSKTTI-UI. Retrieved from http://lib.ui.ac.id/file? file=digital/117210-T\%2024558-\%20perbandingan $\% 20$ faktorHA.pdf

Rosidah, E. (2017). Pengaruh financing to deposit ratio terhadap non performing financing perbankan Syariah di Indonesia. Jurnal Akuntansi, 12, 128-134. http://jurnal.unsil.ac.id/index.php/jak/article/view/385/281

Sari, N., \& Amran, E. (2019). Determinasi non performing financing pada bank umum Syariah di Indonesia. Media Ekonomi, 27(1), 1-8. https://doi.org/10.25105/me.v27i1.5170

Setiawan, C., \& Bagaskara, B. (2016). Non-performing financing (NPF) and cost efficiency of Islamic banks in Indonesia period 2012.Q1 to 2015.Q2. Journal of Emerging Issues in Economic, Finance, and Banking, (1), 1-13. Retrieved from https://globalbizresearch.org/economics/images/files/74631_T632_JEIEFB_Chandra $\% 20$ Setiawan_Bhirawa $\% 20$ Praditya $\% 20$ Bagaskara.pdf.

Setyowati, N. (2019). Macroeconomic determinants of Islamic banking products in Indonesia. Economies 7 (53): 1-15. https://doi.org/10.3390/economies7020053.

Sudarsono, H., Mifrahi, M.M., Susantun, I., Rudatin, A., \& Ruchba, S.M. (2019). Analysis of factor affecting financing with Islamic banks in agriculture sectors. Asian Journal of Islamic Management, 1(1), 80-100. https:// doi.org/10.1108/AJIM.vol1.iss2.art6

Supriani, I., \& Sudarsono, H. (2018). Analisis pengaruh variabel mikro dan makro terhadap NPF perbankan Syariah di Indonesia. Equilibrium: Jurnal Ekonomi Syariah, 6(1), 1-18. https://doi.org/10.21043/equilibrium.v6i1.3040

Tumewang, Y.K., Isnaini, R.N., \& Musta'in, J.L. (2019). The impact of macro economy toward profitability of Islamic bank. Asian Journal of Islamic Management, 1(2), 101-108. https:// doi.org/10.1108/AJIM.vol1.iss2.art4

Widarjono, A. (2009). Ekonometrika pengantar dan aplikasinya (edisi ketiga), Yogyakarta: Ekonisia.

Widarjono, A. (2018). Estimating profitability of Islamic banking in Indonesia. Jurnal Kenangan dan Perbankan, 22(3), 568-579. https://doi.org/10.26905/jkdp.v22i3.2197

Widarjono, A. (2020). Stability of Islamic banks in Indonesia: autoregressive distributed lag Approach. Jurnal Keuangan dan Perbankan, 24 (1), 40-52. https://doi.org/10.26905/jkdp.v24i1.3932. 